\section{EROMM on the Web}

The European Register of Microform Masters (EROMM) is now available on the world Wide Web. It currently contains more than 350,000 bibliographic records of reformatted books held by 32 libraries in 11 European countries. Approximately half the titles are in French and almost a third are in English, with the remainder in other European languages. EROMM intends to facilitate ordering use copies of the titles from the contributing libraries and, therefore, plans to bring up an online ordering service soon.

The Research Libraries Group (RLG) and EROMM signed an agreement last year to exchange records. The first sample of RLG's RLIN records for reformatted books is now visible in the EROMM database. The URL is http: www.brzn.de/eromm/gbvero-e.htm.

\section{Columbia finishes second phase of image project}

Columbia University has finished the second phase of its Oversize Color Images Project and mounted the report on its Web site. The project was clesigned to investigate the use of digital technology for providing access to brittle volumes containing large color maps. Pháse I focused on image quality and the differences between digital images created from originals and microform copies. Phase If focused on matching bitmapped images of text pages scanned from microfilm with digital images of the maps, to create facsimiles of the original volumes. The Web site also contains the report from Phase I of the project, more than 300 images of maps and four complete volumes, text and images, of the New York State Museum bulletin. The URL is http://www.columbia.edu/dlc/nysmb.

\section{Emergency Response update}

The National Task Force on Emergency Response has continued work on its dual mission to safeguard America's cultural heritage from natural disasters and to provide expertise to help the general public recover from disasters. It held a one-day summit in December 1996 to bring together the almost two clozen participating cultural organizations, associations, and governmental agencies. The Association for Library Collections and Technical Services (ALCTS), with its Preservation and Reformatting Section (PARS). represented ALA. The Task Force, through The National Institute for the Conservation of Cultural Property (NIC), has distributed Flood/ Hurricane Information Packets to cultural institutions in the Pacific Northwest.

The Federal Emergency Management Agency (FEMA), as part of its work with the Task Force, has been mounting articles about salvaging cultural materials on its Web site. There is now a list of recommendations and Flood Tips-Saving Water-Damaged Books at http://www.fema.gov/fema/Fldbks.htm.

\section{More Web sites of interest}

The Preservation Service (PRFSERV) of the Research Libraries Group has created a Web page. It includes information about PRESERV, its advisory council, participants, strategic plan, and working groups. This may be of most interest to RLG members, but does inclicate the range of current RLG preservation activities. The URL is http://www.rlg.org/preserv.

Arts, Crafts, and Theater Safety, Inc. (ACTS) has developed a Web site about the hazards posed by the toxic or dangerous materials used in the arts. It offers health and safety counseling, educational and technical information, and referrals to physicians and other sources of professional help. The publications available for sale include a four-page data sheet about understanding Material Safety Data Sheets, and a nine-page data sheet about biological hazards. The URL is http://www.caseweb.com/acts/. Data sheets may be ordered for $\$ .25$ per page from ACTS, 181 Thompson St., \#23, New York, NY 10012-2586; phone: (212) 777-0062; e-mail: ACTS@CaseWeb.Com.

Jane Hedbeng prepares this collm mor the College Libraries Committee, Commission on Presencation and Access. Submissions may be made to: Jane Hedberg. Wellesley College; JHEDBERG@WELIESLYYEI) 